\title{
Pelaksanaan Pendidikan Holistik-Integratif dalam Pelayanan Kebutuhan Dasar Anak Usia Dini di Kabupaten Mamuju Sulawesi-Barat
}

\author{
Kartika Hajati \\ Pendidikan Fisika, Fakultas Keguruan dan Ilmu Pendidikan, Universitas Sulawesi Barat \\ jamil_kartika@yahoo.co.id
}

\begin{abstract}
Abstrak
Pemenuhan kebutuhan dasar anak secara utuh, simultan, dan berkesinambungan dalam keterpaduan (Holistik Integratif) perlu dilakukan sejak dini dalam rangka menciptakan sumber daya manusia bermutu. Tujuan penelitian ini memperoleh deskripsi: 1) Kondisi sasaran Pendidikan Anak Usia Dini Holistik Integratif (PAUD HI) dan akses anak usia dini dalam memperoleh kebutuhan dasarnya, 2) Kondisi mutu layanan dan kelembagaan Bina Keluarga Balita (BKB)-Posyandu-PAUD 3) Faktor pendukung dan penghambat pelaksanaan layanan terpadu BKB-Posyandu-PAUD dan 4) Upaya mengatasi hambatan dalam pelaksanaan layanan terpadu BKB-Posyandu-PAUD dalam rangka implementasi program PAUD HI di Kabupaten Mamuju Provinsi Sulawesi Barat. Objeknya kelompok PAUD SIOLA (Stimulasi Intervensi Optimalisasi Layanan Anak), yakni kelompok PAUD yang merupakan lembaga pemberi layanan BKBPosyandu-PAUD dan Lembaga Keuangan Mikro (LKM). Incidental sampling diterapkan dalam penentuan sampel. Data dikumpulkan melalui metode observasi, wawancara, dan studi dokumentasi. Jumlah keseluruhan anak usia dini di Kabupaten Mamuju 20.217 orang, 8.172 anak terlayani dan 12.045 anak belum terlayani. Adapun mereka yang terlayani di PAUD dan teridentifikasi sebagai anak berusia 0-6 tahun sejumlah 6.451 anak. Berdasarkan angka tersebut dapat diketahui Angka Partisipasi Kasar (APK) anak usia dini baru mencapai 40,42\% (rendah), Proporsi anak usia dini yang bersekolah tepat waktu pun masih rendah, dilihat dari Angka Partisipasi Murni (APM)-nya baru mencapai 31,91\%. Ini mengindikasikan program-program yang ditujukan guna memperluas kesempatan bagi penduduk anak usia dini di Kabupaten Mamuju untuk mengenyam pendidikan, belum menunjukkan keberhasilan. Termasuk didalamnya, program PAUD Holistik Integratif SIOLA yang telah digulirkan sejak tahun 2012. Mutu layanan dan kelembagaan BKBPosyandu-PAUD Holistik Integratif dalam rangka pelayanan kebutuhan dasar anak usia dini di Kabupaten Mamuju masih rendah. Terdapat faktor pendukung pelaksanaan layanan terpadu BKB-Posyandu-PAUD dalam rangka implementasi program PAUD HI di Kabupaten Mamuju Provinsi Sulawesi Barat, yang perlu ditingkatkan pemberdayaannya. Terdapat sejumlah faktor penghambatnya yang meski telah dilakukan upaya mengatasinya, namun belum menunjukkan hasil yang sesuai harapan. Olehnya, perlu terus dilakukan kajian/penelitian menyangkut pelaksanaan PAUD HI di Kabupaten Mamuju, agar ditemukan alternatif solutif guna mengatasi masalah yang dihadapi PAUD HI di Kabupaten Mamuju, Provinsi Sulawesi Barat. Penelitian yang direkomendasikan adalah penelitian yang dapat menghasilkan desain pengembangan anak usia dini terpadu holistik-integratif untuk tingkat Provinsi Sulawesi Barat yang memiliki tingkat keterterimaan tinggi, demikian halnya dengan peluang efektifitasnya. Penelitian demikian dimungkinkan terwujud dengan ancangan penelitian pengembangan (Research and Development $-R \& D$ ).
\end{abstract}

Kata kunci: Holistik-integratif, Anak Usia Dini, Kebutuhan Dasar Anak

\section{PENDAHULUAN}

Kontinuitas pembangunan suatu negara, sangat bergantung pada kualitas sumberdaya manusia (SDM)nya. Kualitas SDM itu sendiri dicerminkan antara lain oleh derajat kesehatan, tingkat intelegensia, kematangan emosional dan spiritual, serta kematangan sosial dan keterampilan motorik individu yang bersangkutan. Semua itu, pada dasarnya ditentukan oleh kualitas individu sejak janin dalam kandungan hingga berusia 6 tahun (anak usia dini), masa yang disebut sebagai periode emas (golden period).

Pada periode ini seorang anak sangat membutuhkan asupan gizi seimbang, kesehatan, pendidikan dan pengasuhan yang baik dan benar agar anak dapat tumbuh kembang secara optimal. Olehnya itu, berbagai upaya perlu dilakukan sejak dini dalam kerangka menciptakan SDM bermutu. Upaya tersebut dilakukan dengan cara memenuhi kebutuhan dasar anak secara utuh, simultan, dan berkesinambungan.

Kebutuhan dasar anak yang dimaksud itu, meliputi kebutuhan fisik-biomedis (asuh), emosi/kasih sayang (asih), dan kebutuhan akan stimulasi mental (asah). Ketiga kebutuhan dasar tersebut saling berkaitan, yang berarti bahwa 
seorang anak membutuhkan asuh, asih dan asah secara simultan, sinergis sesuai dengan perkembangan usia mereka (Panduan Pelaksanaan Kegiatan Bina Keluarga Balita [BKB] yang Terintegrasi dalam Rangka Penyelenggaraan Pengembangan Anak Usia Dini Holistik Integrstif (Badan Kependudukan dan Keluarga Berencana Nasional Jakarta, 2013).

Pemberian layanan kebutuhan dasar anak secara utuh dan terpadu (holistik-integratif) tersebut bagi anak usia dini, di lingkungan masyarakat Indonesia diberikan melalui Pos Pelayanan Terpadu (Posyandu), Bina Keluarga Balita (BKB), Pendidikan Anak Usia Dini (PAUD) dalam berbagai kelompok usia dan kegiatan. Dalam hal ini, pelayanan kesehatan dan gizi serta intervensi deteksi dini, atau kebutuhan fisik-biomedis (asuh) dilakukan melalui pelayanan posyandu, pelayanan kebutuhan stimulasi mental (asah) anak dilakukan melalui PAUD, dan dukungan terhadap pemenuhan kebutuhan emosi/kasih sayang serta perlindungan terhadap anak dilakukan melalui berbagai kegiatan Bina Keluarga Balita (BKB).

Pelaksanaan kegiatan tersebut, hendaknya dilakukan secara holistik terintegrasi, tidak bersifat sektoral, parsial. Jika melihat substansi layanan kegiatan dan tujuannya pun, BKB, Posyandu, dan PAUD itu sesungguhnya dapat disinergikan, karena satu sama lain saling mengisi dan melengkapi. Terutama, bila hal ini dikaitkan dengan kebutuhan tumbuh kembang anak secara optimal yang mengandung makna holistik, mencakup perkembangan kognitif, mentalemosional (afektif), dan keterampilan fisik-motorik disertai keterampilan sosial (psikomotorik). Demikian halnya jika dikaitkan dengan tujuan pendidikan nasional yang juga bermakna holistik pula yakni “.... berkembangnya potensi peserta didik agar menjadi manusia yang beriman dan bertakwa kepada Tuhan Yang Maha Esa, berakhlak mulia, sehat, berilmu, cakap, kreatif, mandiri, dan menjadi warga negara yang demokratis serta bertanggung jawab. (UU. No. 20 Tahun 2003 tentang Sistem Pendidikan Nasional).

Pemberian layanan kebutuhan dasar anak melalui Posyandu, BKB, dan PAUD yang dilakukan secara sektoral, parsial, mengakibatkan ketidakefektifan pelaksanaan, dan hasil layanannya juga tidak utuh. Dengan demikian tidak mendukung optimalisasi tumbuh kembang anak subjek sasaran layanan program, serta tidak seirama dengan pencapaian tujuan nasional pendidikan Indonesia yang mestinya terjadi secara holistik. Singkatnya, layanan yang diberikan melalui BKB, Posyandu, maupun PAUD yang dilakukan secara sektoral, parsial, tidak akan menjadi daya dukung ataupun daya ungkit peningkatan kualitas sumberdaya manusia, khususnya tumbuh kembang anak secara potensial optimal.

Oleh karena itu, terselenggaranya layanan kebutuhan dasar secara holistik integratif bagi anak usia dini, merupakan hal yang urgen dan mendesak untuk dilakukan. Maka pemberian layanan kebutuhan dasar anak melalui Posyandu, BKB, dan PAUD yang dilakukan secara sektoral, parsial, merupakan masalah yang urgen dan mendesak pula untuk segera diatasi.

Pengembangan Anak Usia Dini Holistik-Integratif (PAUD H-I), merupakan upaya pengembangan Anak Usia Dini yang dilakukan untuk memenuhi kebutuhan esensial anak yang beragam dan saling terkait secara simultan, sistematis, dan terintegrasi (Perpres No. 60 /2013, Ps.1 Butir 2). Adapun pengertian strategi implementasi PAUD (Pembinaan Anak Usia Dini) Terpadu Holistik Integratif dalam penelitian ini, adalah program layanan intervensi bagi anak usia dini (0-6) tahun dengan menyelenggarakan PAUD (Pendidikan Anak Usia Dini)-BKB-Posyandu untuk melayani kebutuhan dasar anak (Asah: stimulasi pendidikan; Asih: kasih sayang, kesejahteraan, perlin-dungan', dan Asuh: fisik biomedis terkait gizi dan kesehatan) secara simultan dan sistematis yang dalam pembinaan, penyelenggaraan dan pengelolaannya dilakukan secara terpadu atau terkoordinasi.

Merujuk Bappenas, PAUD Terpadu Holistik Integratif merupakan pengembangan anak usia dini yang dilakukan berdasarkan pemahaman untuk memenuhi kebutuhan esensial anak yang beragam dan saling berkait secara simultan sistematis (2006). Adapun menurut Direktorat Pembinaan PAUD, holistic artinya penanganan anak usia dini secara utuh/menyeluruh yang mencakup layanan gizi dan kesehatan, pendidikan dan pengasuhan, dan perlindungan, untuk mengoptimalkan semua aspek perkembangan anak. Integratif/terpadu artinya penanganan di tingkat masyarakat, pemerintah daerah, dan pusat. (KementrianNegara Perencanaan Pembangunan, 2006) .

Tujuan PAUD (Pembinaan Anak Usia Dini) Terpadu yakni: meningkat-kan tata kelola dan kapasitas lembaga PAUD, meningkatkan efisiensi dan efektifitas dalam perencanaan, pelaksanaan dan pengelolaan layanan PAUD. Sebuah lembaga disebut sebagai PAUD Terpadu apabila telah memenuhi syarat: (1) memiliki ijin operasional/pendirian lembaga PAUD, (2) memiliki struktur organisasi kepengurusan, (2) memiliki minimal 2 program PAUD (TK, KB, TPA, SPS), (3) memiliki peserta didik minimal 20 anak setiap jenis program, (4) memiliki pendidik dan tenaga kependidikan, (5) rencana kerja dan rencana pembelajaran, sesuai program, (6) memiliki alat permainan edu-katif, (7) memiliki NPWP, (8) memiliki surat bukti kepemilikan gedung/lahan.

\section{Metode}

Metode penelitian menurut Sugiono, yaitu "Cara ilmiah untuk mendapatkan data dengan tujuan dan kegunaan tertentu.", (2007:3). Berikut ini, diuraikan mengenai cara ilmiah yang dilakukan dalam penelitian ini. 


\section{a. Tipe Penelitian}

Penelitian ini menggunakan tipe deskriptif dengan pendekatan kuantitatif. Menurut Sugiyono, penelitian deskriptif yaitu penelitian yang dilakukan untuk mengetahui nilai variabel mandiri, baik satu variabel atau lebih (independen) tanpa membuat perbandingan, atau menghubungkan dengan variabel yang lain. (2012:8).

Penelitian deskriptif cocok dengan konteks penelitian ini yang terdiri dari variabel mandiri, dengan demikian tanpa membuat perbandingan, atau menghubungkan dengan variabel yang lain. Disamping itu, metode deskriptif cocok untuk mencapai tujuan penelitian yang mengungkap permasalahan-permasalahan yang ada pada saat penelitian dilakukan. Sesuai dengan judul penelitian ini, hendak mengungkap permasalahan permasalahan yang ada pada saat penelitian dilakukan menyangkut pelaksanaan BKB-Posyandu-PAUD holistik integratif dalam pelayanan hebutuhan dasar anak usia dini di Kabupaten Mamuju Provinsi Sulawesi Barat.

\section{b. Objek, Waktu, dan Tempat Penelitian}

Objek penelitian adalah sifat keadaan dari suatu benda, orang, atau yang menjadi pusat perhatian dan sasaran penelitian. Sifat keadaan dimaksud bisa berupa sifat, kuantitas, dan kualitas yang bisa berupa perilaku, kegiatan, pendapat, pandangan penilaian, sikap pro-kontra, simpati-antipati, keadaan batin, dan bisa juga berupa proses. Menurut Sugiyono, objek penelitian yaitu "Suatu atribut atau sifat atau nilai dari orang, objek atau kegiatan yang mempunyai variasi tertentu yang ditetapkan oleh peneliti untuk dipelajari dan kemudian ditarik kesimpulannya" (2012:303).

Penelitian ini dilaksanakan di wilayah Kabupaten Mamuju, tempat objek penelitian berada. Objek sasarannya, yakni lembaga-lembaga PAUD yang sudah ditentukan oleh pemerintah daerah tersebut, untuk melayani anak usia dini dalam memenuhi kebutuhan dasarnya melalui pelayanan yang menyeluruh dalam keterpaduan (Holistic Integratif). Di Kabupaten Mamuju, layanan demikian dipayungi oleh program yang disebut sebagai layanan SIOLA.

SIOLA itu sendiri, secara terminologi merupakan akronim dari Stimulasi Intervensi Optimalisasi Layanan Anak. Secara etimologi, SIOLA merupakan nama yang diambil dari bahasa Mandar yang berarti bersama-sama/saling gotong royong. Adapun secara kontekstual, SIOLA artinya bersama-sama - bersatu dalam memberikan pelayanan terhadap anak berusia 0-6 tahun, para ibu dan keluarganya.

SIOLA dilaksanakan secara holistik, integrative dan partisipatif, dengan memperluas kesempatan bagi setiap anak usia emas untuk memperoleh dan menikmati pendidikan usia dini. Melalui program SIOLA pemerintah Kabupaten Mamuju berkomitmen untuk mendorong dan mendukung pembinaan anak usia dini dalam bentuk program dan kegiatan, serta mendorong keterlibatan keluarga untuk mengambil peran yang lebih besar dalam pengasuhan perlindungan, dan perkembangan anak.

SIOLA merupakan program unggulan pemerintah Kabupaten Mamuju sejak tahun 2012. Ini diperkuat dengan SK Bupati Nomor 1 tahun 2012 tentang pembentukan GUGUS SIOLA. Kegiatan SIOLA, tidak lepas dari peran serta anggota/masyarakat bersama pemerintah setempat, pemuka agama dan instansi terkait dalam pembinaan tumbuh kembang anak secara komprehensif dan berkualitas yang diselenggarakan melalui kegiatan Stimulasi, Intervensi, Optimalisasi. Layanan Anak terpadu antara Dinas Pendidikan Pemuda dan Olah Raga, Dinas Kesehatan, Dinas Koperasi dan Perdagangan, dan Biro Pemberdayaan Perempuan dan Keluarga Berencana (Biro PP dan KB), serta Bappeda Kabupaten Mamuju.

Sampling Insidental diterapkan dalam menentukan anggota sampel penelitian ini. Menurut Sugiyono, Teknik sampel insidental adalah teknik penentuan sampel berdasarkan kebetulan, yaitu siapa saja yang secara kebetulan/insidental bertemu dengan peneliti dapat digunakan sebagai sampel, bila dipandang orang yang kebetulan ditemui itu cocok sebagai nara sumber (2011:85). Penerapannya dapat digambarkan sebagai berikut.

Peneliti langsung mendatangi tempat lembaga yang telah teridentifikasi sebagai PAUD SIOLA, tanpa pemberitahuan terlebih dahulu kepada pengurusnya. Hal ini dilakukan agar keadaannya benar-benar riil, tidak dimanipulasi sedemikian rupa. Lembaga PAUD SIOLA yang kemudian masuk menjadi anggota sampel yakni: (1) ketika peneliti datangi untuk diambil datanya, lembaga tersebut masih aktif (karena ada lembaga PAUD SIOLA yang ternyata sudah tidak aktif lagi/tidak melaksanakan program lagi), (2) Ketika peneliti mendatangi PAUD tempat sasaran sedang melakukan aktifitas pembelajaran, serta pengurusnya bersedia diwawancarai serta memberi keterangan yang dibutuhkan.

\section{Pembahasan}

Uraian berikut ini menggambarkan paparan data dan pembahasan hasil penelitian "Pelaksanaan BKB-Posyandu-PAUD Holistik Integratif dalam Pelayanan Kebutuhan Dasar Anak Usia Dini di Kabupaten Mamuju Provinsi Sulawesi Barat.”

A. Kondisi Sasaran PAUD HI dan Akses Anak Usia Dini dalam Memperoleh Kebutuhan Dasarnya di Kabupaten Mamuju Provinsi Sulawesi Barat 
1. Sasaran Pengembangan Anak Usia Dini dengan Pendekatan Holistik Integratif (PAUD HI) di Kabupaten Mamuju

a. Sasaran langsung : anak usia dini $(0-6$ tahun $)$

b. Sasaran tidak langsung: orang tua peserta didik, keluarga, kader, tenaga kesehatan dan gizi, tenaga pendidik, pengasuh, masyarakat, organisasi sosial masyarakat, para pengambil kebijakan, berbagai provider dan stakeholder lainnya yang relevan dengan terpenuhinya kebutuhan dasar (essensial) anak usia dini.

2. Kondisi Akses Layanan Pengembangan Anak Usia Dini Holistik Integratif (PAUD HI) di Kabupaten Mamuju Kondisi AUD di Kabupaten Mamuju sampai akhir Desember 2015 tercatat telah terlayani sebanyak 6.451 anak dari jumlah anak usia dini 20.217 anak, atau baru mencapai 31,91\%. Selanjutnya, diketahui Angka Partisipasi Kasar (APK)-nya 30,91\% (rujuk tabel 4.2).

Berdasarkan Angka Partisipasi Kasar anak usia dini sebesar 30,90\% (rendah) ini, mengindikasikan bahwa program-program yang ditujukan guna memperluas kesempatan bagi penduduk anak usia dini di Kabupaten Mamuju untuk mengenyam pendidikan, hingga sekarang ini, belum menunjukkan keberhasilan. Termasuk didalamnya, program PAUD HI SIOLA yang digulirkan sejak tahun 2012. Oleh karena itu, PAUD HI harus terus digalakkan dan diperbaiki kekurangan-kekurangannya, bukan saja akses pelayanan yang seyogiyanya ditingkatkan, tetapi juga mutu layanannya.

Data lebih rinci menunjukkan bahwa semua kecamatan memiliki angka partisipasi kasar anak usia dini berada pada kisaran 0\% s/d 39,55\%. APK terendah dialami oleh kecamatan Balabalakang, semua anak usia dini (204 orang) di kecamatan tersebut belum terlayani. Adapun kecamatan yang memiliki anak usia dini terbanyak tidak terlayani yaitu Kecamatan Kaluku, sebesar 2.686 anak. Oleh karena itu, Kecamatan Balabalakang dan Kaluku harus diprioritaskan untuk diberi bantuan pengadaan maupun bantuan kebutuhan operasional PAUD HI (PAUD-BKB-Posyandu).

Tentu, perhatian juga diberikan kepada sembilan kecamatan lainnya. Hal itu mengingat pada setiap kecamatan itu memiliki angka yang cukup besar dalam hal anak usia dini yang belum terlayani PAUD dari mulai 352 anak s/d 1.668 anak. Ini mengindikasikan bahwa amanah dari UU RI Nomor. 23 Tahun 2002 Pasal 9 Ayat 1 tentang Perlindungan Anak dinyatakan bahwa setiap anak berhak memperoleh pendidikan dalam rangka pengembangan pribadinya dan tingkat kecerdasannya sesuai dengan minat dan bakatnya, tidak terpenuhi. Disamping itu, pelanggaran juga terhadap UU RI No. 20 Tahun 2003 Pasal 28 C Ayat 2 yang menyatakan bahwa setiap anak berhak mengembangkan diri melalui pemenuhan kebutuhan dasarnya, berhak mendapatkan pendidikan dan memperoleh manfaat dari ilmu pengetahuan dan teknologi, seni dan budaya, demi meningkatkan kualitas hidupnya dan demi kesejahteraan umat manusia.

Tabel : 4.1

Pelayanan Anak Usia Dini Per Kecamatan dan Jenis Kelamin

Di Kabupaten Mamuju Provinsi Sulawesi Barat Tahun 2015

\begin{tabular}{|c|c|c|c|c|c|c|c|c|c|c|c|c|c|}
\hline \multirow[t]{2}{*}{ NO } & \multirow[t]{2}{*}{ KECAMATAN } & \multicolumn{2}{|c|}{$\begin{array}{c}\text { Jumlah } \\
\text { Penduduk AUD }\end{array}$} & \multirow[t]{2}{*}{$\begin{array}{l}\text { Jumlah } \\
\text { AUD } \\
\text { (L+P) }\end{array}$} & \multirow[t]{2}{*}{$\%$} & \multicolumn{2}{|c|}{$\begin{array}{c}\text { ANAK } \\
\text { TERLAYANI } \\
\text { (L DAN P) }\end{array}$} & \multirow{2}{*}{$\begin{array}{c}\text { Jumlah } \\
\text { Anak } \\
\text { Terlaya } \\
\text { ni }\end{array}$} & \multirow[t]{2}{*}{$\%$} & \multicolumn{2}{|c|}{$\begin{array}{c}\text { ANAK BELUM } \\
\text { TERLAYANI } \\
\text { (L DAN P) }\end{array}$} & \multirow{2}{*}{$\begin{array}{c}\text { Jumlah } \\
\text { Anak } \\
\text { belum } \\
\text { Terlayani } \\
(\mathbf{L}+\mathbf{P})\end{array}$} & \multirow[t]{2}{*}{$\%$} \\
\hline & & $\mathrm{L}$ & $P$ & & & $\mathrm{~L}$ & $P$ & & & $\mathrm{~L}$ & $\mathrm{P}$ & & \\
\hline 1 & Tapalang & 856 & 797 & 1.653 & 8,17 & 224 & 222 & 446 & 6,91 & 576 & 508 & 1.084 & 8,99 \\
\hline 2 & Tapalang Barat & 581 & 489 & 1.070 & 5,29 & 152 & 144 & 296 & 4,58 & 391 & 312 & 703 & 5,83 \\
\hline 3 & Mamuju & 1.931 & 1.693 & 3.629 & 17,95 & 683 & 606 & 1.289 & 19,98 & 1.065 & 917 & 1.982 & 16,45 \\
\hline 4 & Simboro & 1.279 & 1.239 & 2.518 & 12,45 & 352 & 341 & 693 & 10,74 & 846 & 822 & 1.668 & 13,84 \\
\hline 5 & Balabalakang & 104 & 100 & 204 & 1,00 & - & - & - & - & 104 & 100 & 204 & 1,69 \\
\hline 6 & Kalukku & 2.518 & 2.309 & 4.827 & 23,87 & 853 & 856 & 1.709 & 26,49 & 1.454 & 1.232 & 2.686 & 22,29 \\
\hline 7 & Papalang & 850 & 841 & 1.691 & 8,36 & 278 & 279 & 557 & 8,63 & 465 & 462 & 927 & 7,69 \\
\hline 8 & Sampaga & 576 & 509 & 1.085 & 5,36 & 118 & 136 & 254 & 3,93 & 430 & 332 & 762 & 6,32 \\
\hline 9 & Tommo & 980 & 873 & 1.853 & 9,16 & 285 & 293 & 578 & 8,95 & 621 & 510 & 1.131 & 9.38 \\
\hline 10 & Kalumpang & 536 & 488 & 1.024 & 5,06 & 224 & 181 & 405 & 6,27 & 275 & 271 & 546 & 4,53 \\
\hline 11 & Bonehau & 365 & 298 & 663 & 3,27 & 131 & 93 & 224 & 3,47 & 181 & 171 & 352 & 2,92 \\
\hline \multicolumn{2}{|c|}{ Kabupaten Mamuju } & 10.576 & 9.636 & 20.217 & 100 & 3.300 & 3.151 & 6.451 & 100 & 6.408 & 5.637 & 12.045 & 100 \\
\hline
\end{tabular}

Sumber: Hasil Pendataan Sistem Informasi Pendidikan Berbasis Masyarakat (SIPBM) Kabupaten Mamuju Tahun 2015 Kerjasama Pemerintah Kabupaten Mamuju, Unicef dan Yayasan Karampuang) 
Fenomena lanjut yang dapat diketahui tentang pemerolehan pelayanan kebutuhan dasar anak usia dini di Kabupaten Mamuju, yakni dari jumlah keseluruhan anak usia dini sejumlah 20.217 anak, belum terlayani 12.045 anak. Adapun mereka yang terlayani di PAUD dan teridentifikasi sebagai anak berusia 0-6 tahun sejumlah 6.451 anak, maka sisanya sejumlah 1.721 anak dapat diduga mereka itu anak yang bersekolah di PAUD tetapi usianya di atas 6 tahun. Terhadap fenomena ini, Dinas Pendidikan Pemuda dan Olah raga Kabupaten Mamuju perlu mendalami lebih lanjut, tentang akses mengikuti pendidikan dasar tingkat satuan Sekolah Dasar dan Pendidikan Dasar (SD dan SMP bagi anak berkebutuhan khusus).

Tabel 4.2

Angka Partisipasi Kasar (APK) Anak Usia Dini Per Kecamatan di Kabupaten Mamuju

\begin{tabular}{|c|c|c|c|c|}
\hline $\mathrm{NO}$ & KECAMATAN & $\begin{array}{l}\text { Jumlah Anak } \\
\text { Terlayani } \\
\text { (L+P) }\end{array}$ & $\begin{array}{l}\text { JUMLAH } \\
\text { PAUD } \\
(\mathrm{L}+\mathrm{P})\end{array}$ & $\begin{array}{c}\text { APK } \\
(\%)\end{array}$ \\
\hline 1. & Tapalang & 446 & 1.653 & 26,98 \\
\hline 2. & Tapalang Barat & 296 & 1.07 & 27,66 \\
\hline 3. & Mamuju & 1,289 & 3.629 & 35,51 \\
\hline 4. & Simboro & 693 & 2.518 & 27,52 \\
\hline 5. & Balabalakang & - & 204 & 0 \\
\hline 6. & Kalukku & 1.709 & 4.827 & 35,4 \\
\hline 7. & Papalang & 557 & 1.691 & 32,93 \\
\hline 8. & Sampaga & 254 & 1.085 & 23,41 \\
\hline 9. & Tommo & 578 & 1.853 & 31,19 \\
\hline 10. & Kalumpang & 405 & 1.024 & 39,55 \\
\hline 11. & Bonehau & 224 & 663 & 33,78 \\
\hline & Kabupaten Mamuju & 6.451 & 20.217 & 31,91 \\
\hline Sumber & \multicolumn{4}{|c|}{$\begin{array}{l}\text { Hasil Pendataan Sistem Informasi Pendidikan Berbasis Masyarakat (SIPBM) } \\
\text { Kabupaten Mamuju Tahun } 2015 \text { (Kerjasama Pemerintah Kabupaten } \\
\text { Mamuju, Unicef dan Yayasan Karampuang) }\end{array}$} \\
\hline
\end{tabular}

B. Kondisi Mutu Layanan dan Kelembagaan BKB-Posyandu-PAUD HI dalam Rangka Pelayanan Kebutuhan Dasar Anak Usia Dini sebagai Implementasi PAUD HI di Kabupaten Mamuju Provinsi Sulawesi Barat

Jenis-jenis pelayanan yang ditujukan untuk melayani kebutuhan dasar anak usia dini yang ada di Kabupaten Mamuju, mencakup: Tempat Penitipan Anak (TPA), Kelompok Bermain, TK/Raudatul Athfal, Bina Keluarga Balita (BKB), Pos Pelayanan Terpadu (Posyandu), Taman Pendidikan Al-Quran (TPQ), dan Sekolah Minggu. Diantara jenis pelayanan tersebut, yang sudah dirancang untuk dilaksanakan secara integratif melalui Program PAUD SIOLA mencakup: PAUD-BKB-Posyandu yang tersebar pada semua Kecamatan di Kabupaten Mamuju.

Adapun kondisi layanan PAUD yang dikatakan telah dirancang pengelolaannya untuk dapat terpadu holistik integratif tersebut, pencapaiannya hingga penelitian ini dilakukan, dapat digambarkan sebagai berikut:

1. Keadaan Sarana dan Prasarana PAUD Terpadu Holistik Integratif (PAUD SIOLA) di Kabupaten Mamuju Provinsi Sulawesi Barat:

a. Keadaan Bangunan/Gedung Tempat Kegiatan PAUD Terpadu HI

1) Bangunan/gedung PAUD Terpadu HI kondisinya sederhana dan apa adanya, sebagian besar membutuhkan renovasi karena keadaannya belum memadai (sebagian besar dindingnya rapuh, atapnya bocor-bocor), jendela dan pintu rapuh. Dapat dikatakan, prinsip kenyamanan dan keamanan tempat kegiatan belum mendapat perhatian yang memadai. Dengan kondisi bangunan demikian, anak tidak dapat berkonsentrasi dengan baik ketika mengikuti aktifitas pembelajaran, terlebih lagi kalau hujan. Demikian juga tendik dan kader yang mengkhawatirkan keadaan bangunan yang tidak memberi keamanan dan kenyamanan bagi pengguna yang 
beraktifitas didalamnya itu.

2) Bangunan/gedung yang digunakan untuk melaksanakan PAUD Terpadu Holistik Integratif, hampir semua memiliki pencahayaan dan sirkulasi udara yang baik. Namun, masih banyak diantaranya yang tidak dilengkapi sanitasi dasar yang mencakup air bersih, tempat cuci tangan, dan kakus/WC. Keadaan demikian menunjukkan bangunan/gedung tersebut belum sepenuhnya memenuhi persyaratan kesehatan. Akibat yang terjadi dari kondisi demikian, berefek negatif terhadap kesehatan anak, kurang terdukungnya upaya pembentukan dan penguatan karakter positif berupa pembiasaan hidup bersih dan sehat pada anak usia dini (peserta didik) khususnya dan masyarakat umumnya. Adapun program-program yang berkaitan pembiasaan hidup sehat misalnya: 'membiasakan cuci tangan memakai sabun', 'membiasakan buang air kecil dan buang air besar pada tempatnya', serta program-program kesehatan lainnya yang lebih besar.

3) Bangunan/gedung PAUD Terpadu Holistik Integratif yang ada, jumlah ruangan sangat terbatas, sehingga kurang mendukung efektifitas pelayanan: program yang sedianya akan dilaksanakan dalam rangkaian satu waktu. Seringkali terjadi 'konflik kegiatan' (conflicting activities) karena satu ruangan digunakan untuk dua atau tiga aktifitas pembelajaran yang berbeda, dengan kelompok yang berbeda, diwaktu yang sama. Olehnya, peserta didik tidak dapat berkonsentrasi, dan mobilitas anak terganggu terutama jika pembelajaran/bermain yang sedang berlangsung memerlukan gerak tubuh atau aktifitas yang penuh gerak dan perpindahan (mobilitas). Sementara kegiatan pembelajaran kelompok lainnya melakukan aktifitas yang pasif dan tenang.

4) Ruangan dan/atau halaman tempat bermain terlalu sempit. Dapat dikatakan, bahwa persyaratan "memiliki halaman yang cukup luas untuk bermain dengan bebas, leluasa, dan kenyamanan anak dalam bermain dan beraktifitas belajar lainnya", belum mendapat perhatian yang memadai. Akibatnya, anak usia dini tidak terdukung dalam hal perkembangan kognitif, fisik, dan sosio-emosinya, mencakup: a) pengembangan keterampilan motorik kasar, meliputi: pengembangan ketangkasan, keseimbangan, kekuatan, kelenturan, kelincahan, koordinasi, dan kecepatan dalam pola gerakan lokomotor dan non lokomotor, b) pengembangan motorik halus meliputi koordinasi mata, tangan dan jari-jari tangan, c) pengembangan kemampuan berpikir, persepsi terhadap ruang, dan imajinasi, d) merencanakan dan memiliki banyak ide, e) memecahkan masalah, f) mengembangkan dan menggali pengalaman, g) pengembangan rasa percaya diri, keberanian, kemandirian, tanggung jawab, toleransi, bekerjasama, membuat keputusan, dan mengenal aturan.

\section{Kesimpulan}

Kondisi anak usia dini (usia 0-6 tahun) di Kabupaten Mamuju Provinsi Sulawesi Barat, masih cukup memprihatinkan. Angka Partisipasi Kasar anak usia dini di Kabupaten Mamuju sampai akhir Desember 2015 baru mencapai 30,91\% (rendah). Ini mengindikasikan bahwa program-program yang ditujukan guna memperluas kesempatan bagi penduduk anak usia dini di Kabupaten Mamuju untuk mengenyam pendidikan, hingga saat penelitian ini dilakukan (tahun 2016), belum menunjukkan keberhasilan. Termasuk didalamnya, program PAUD Holistik Integratif SIOLA yang digulirkan sejak tahun 2012. Selanjutnya, dapat dikatakan bahwa kebutuhan dasar anak usia dini belum secara utuh terpenuhi, belum secara maksimal terlayani, baik dari segi perawatan, pendidikan, dan pengasuhan. Dengan demikian, memunculkan indikasi lebih lanjut lagi, yakni anak usia dini di Kabupaten Mamuju Provinsi Sulawesi Barat belum terdukung optimalisasi tumbuh kembangnya.

1. Kondisi mutu layanan dan kelembagaan BKB-Posyandu-PAUD Holistik Integratif dalam rangka pelayanan kebutuhan dasar anak usia dini di Kabupaten Mamuju Provinsi Sulawesi Barat, masih rendah. Hal ini ditunjukkan dengan: (a) keadaan sarana dan prasarana yang belum memadai, (b) ketersediaan sumber daya manusia pengelolanya (tenaga pendidik, kader, tenaga kesehatan, maupun staf administrasi) belum sesuai dengan kebutuhan baik dari segi jumlah, kompetensi, maupun keterlibatan-nya dalam kegiatan), (c) keterlaksanaan sinergitas penyelenggaraan PAUD Terpadu Holistik Integratif (PAUD SIOLA) masih lemah, baik sinergitas antara pengelola dengan SKPD terkait di tingkat Kabupaten maupun Provinsi, LSM yang terlibat dalam pengembangan program, maupun sinergitas antara pengurus dengan orangtua dan masyarakat. Disamping itu, masih lemah pula sinergitas antara kurikulum (isi layanan) antara BKB-Posyandu-PAUD dan LKM; serta hal sinergitas waktu pelaksanaan dan tempat penyelenggaraan (waktu penyelenggaraan tidak sama-dan-tempat penyelenggaraan yang berbeda lokasi).

2. Terdapat faktor pendukung dalam pelaksanaan layanan terpadu BKB-Posyandu-PAUD dalam rangka implementasi program PAUD HI di Kabupaten Mamuju Provinsi Sulawesi Barat, yang perlu ditingkatkan pemberdayaannya. Faktor pendukung tersebut mencakup: (a) adanya kebutuhan yang tinggi terhadap keberadaan PAUD HI, ditunjukkan dengan Angka Partisipasi Kasar anak usia dini yang masih rendah yakni 30,91\% (b) Semakin meningkatnya jumlah orang tua anak usia dini yang memiliki kepedulian dan kesadaran akan pentingnya pemberian layanan kebutuhan dasar anak secara holistik terintegrasi yang berkualitas (c) terdapat sejumlah satuan (lembaga) yang bertujuan melayani kebutuhan dasar anak usia dini di Kabupaten Mamuju yang sudah terbentuk, dan melaksanakan aktifitasnya (ini berpotensi sebagai embrio PAUD HI), (d) adanya kesediaan Organisasi Perangkat Daerah (OPD) terkait baik di 
tingkat kabupaten maupun provinsi, untuk menggulirkan program-programnya yang mendukung penyelenggaraan PAUD HI, dalam kerangka 'terintegrasi', serta (e) Masih relatif banyak, masyarakat yang peduli dan memiliki kesediaan untuk turut mengurusi penyelenggaraan PAUD HI.

3. Upaya mengatasi hambatan dalam pelaksanaan layanan terpadu BKB-Posyandu-PAUD dalam rangka implementasi program PAUD HI di Kabupaten Mamuju Provinsi Sulawesi Barat:

a. Pemerintah Kabupaten Mamuju, telah mengupayakan pengadaan lahan dan/atau memastikan status tanah/gedung PAUD HI, tetapi hasilnya belum sesuai harapan.

b. Lembaga PAUD HI (PAUD SIOLA) yang sekarang aktif, hendaknya mengadakan penambahan jumlah ruang, dan penambahan ukuran ruang pelayanan, juga tempat bermain, sehingga representatif.

c. Penyelenggara PAUD HI (PAUD SIOLA) hendaknya merancang kegiatan BKB-Posyandu-PAUD untuk dapat dilakukan pada keadaan "sama waktu dan tempat pelaksanaan", agar koordinasi sinergitas segala aspek (biaya, tenaga, dan materi/isi kegiatan, dll.) saling dapat mengisi/melengkapi, dan terjadi sinkronisasi dalam segala segi, hingga efektifitas pelayanan PAUD HI dapat dimaksimalkan.

d. Penyelenggara PAUD Holistik-Integratif hendaknya merancang dan melaksanakan kegiatan sosialisasi untuk meningkatkan intensitas keterlibatan dan kepedulian masyarakat luas.

e. Pengelola PAUD HI (PAUD SIOLA) Kabupaten Mamuju, hendaknya mengupayakan peningkatan pemberdayaan 'Lembaga Keuangan Mikro' (LKM) agar lembaga ini bukan hanya dapat berfungsi menguatkan keberdayaan orangtua dalam memenuhi kebutuhan anaknya maupun meningkatkan wira usahanya, tetapi juga dapat membantu pengelola (tendik, kader, petugas administrasi) untuk meningkatkan kesejahteraannya, melalui penerimaan insentif yang ditambah dan keteraturan penerimaannya setiap bulan.

f. Untuk meningkatkan kompetensi tendik, kader, maupun petugas administrasi pengelola PAUD SIOLA, termasuk pengelola LKM, pelatihan-pelatihan harus ditambah jumlahnya maupun variasi isi pelatihan.

g. LSM yang diberi tanggung jawab oleh pemerintah kabupaten, melalui kesepakatan yang telah dibangun kedua belah pihak untuk menyelenggarakan pengembangan GUGUS SIOLA sebagai realisasi dari program PAUD HI di Kabupaten Mamuju, hendaknya: (1) lebih terbuka kepada masyarakat luas dan pemerintah dalam memberikan informasi tentang aktifitas GUGUS SIOLA, (2) lebih terbuka dalam pemberian informasi mengenai ketercapaian efektifitas PAUD SIOLA, dan (3) berupaya meningkatkan koordinasi dengan berbagai pihak terkait.

\section{Referensi}

Ahmad Susanto. (2012). Perkembangan Anak Usia Dini. (2012). Prenada Media.

Badan Kependudukan dan Keluarga Berencana Nasional Jakarta. (2013) Panduan Pelaksanaan Kegiatan Bina Keluarga Balita (BKB) yang Terintegrasi dalam Rangka Penyelenggaraan Pengembangan Anak Usia Dini Holistik Integratif.

Bungin, Burhan H.M, (2007); Penelitian Kualitatif : Komunikasi, Ekonomi, Kebijakan Publik, dan Ilmu sosial, Jakarta : Kencana Prenama Media Group.

Deputi Bidang SDM dan Kebudayaan. (2009). Pengembangan Anak Usia Dini Holistik-Integratif; Pedoman Umum. Jakarta: Deputi Bidang SDM dan Kebudayaan Bappenas.

Direktorat Pembinaan Pendidikan Anak Usia Dini. (2013). NSPK Petunjuk Teknis Penyelenggaraan Pos PAUD.

Imas Kurniasi. (2013). Pendidikan Anak Usia Dini. Edukasia.

Helmawati. (2015). Mengenal dan Memahami PAUD. Bandung: PT. Remaja Rosdakarya

Kementerian Kesehatan RI, Pusat Promosi Kesehatan. (2012). Buku Saku Posyandu: Ayo ke Posyandu Setiap Bulan.

Maemunah Hasan. (2009). PAUD (Pendidikan Anak Usia Dini). Diva Press.

Pratisti, Wiwied D. (2008). Psikologi Anak Usia Dini. Indeks.

Peraturan Menteri dalam Negeri Nomor 19 Tahun 2011 Tentang Pedoman Pengintegrasian Layanan Sosial Dasar di Pos Pelayanan Terpadu.

Peraturan Menteri Pendidikan dan Kebudayaan Republik Indonesia Nomor 137 Tahun 2014 Tentang Standar Nasional Pendidikan Anak Usia Dini. 
Pusat Kurikulum Badan Penelitian dan Pengembangan Departemen Pendidikan Nasional. (2007). Konsep pengembangan kurikulum pendidikan anak usia dini formal.

Rosihan M. Materi Penyuluhan : 1000 Hari Pertama Kehidupan. https://mohamadrosihanwordpresscom2014.

Sudjana. (1996). Metode Statistika, Bandung: Tarsito..

Sugiyono. (2004). Statistik untuk Penelitian, Bandung: Alfabeta

-(2007). Konsep pengembangan kurikulum pendidikan anak usia dini nonformal.

(2010). Metode Penelitian Kuantitatif Kualitatif dan R \& D. Bandung: Alfabeta.

(2011). Metode Penelitian Kuantitatif, Kualitatif dan R \& D. Bandung: Alfabeta.

(2013). Metode Penelitian Kuantitatif, Kualitatif, Kualitatif dan R \& D. Cetakan Ke-19. Bandung: Alfabeta.

(2015). Metode Penelitian Kombinasi (Mixed Methods). Bandung: Alfabeta. 